\title{
ANALYTICAL STUDY OF POLITICS IN BANGLADESH : AGES OF SHEIKH HASINA AND KHALEDA ZIA'S DICTATES
}

\author{
Mohammad Eisa Ruhullah'1, Zuly Qodir ${ }^{2}$ \\ 1,2 Master of the Government Affairs and Administration, Jusuf Kalla School of Government and \\ University of Muhammadiyah Yogyakarta, Indonesia \\ Corresponding author E-mail : eisa.iium@gmail.com
}

\begin{abstract}
Establishing a healthy and competitive democratic method remained a distant dream for a lengthy time to get to Bangladesh. The attain sociopolitical integration and sustainable development which is essential for establishing a peaceful democratic society in Bangladesh. This research to examine the leadership of H. E. Shaikh Hasina and Begum Khaleda Zia with Bangladesh Awami League and Bangladesh National Party. By using a qualitative approach this research aims The study to measure the implication of democracy via both leaders during their regimes. It must find out the solution of the current problems of the political transformation and accountability among the political parties (administrations). The writing obtains to a final decision on the leading method of both ladies in Bangladesh was lacking sustainable development in politics and lacking mutual trust plus understanding among them. Moreover, this study explores that the real challenge to a free and fair national election in Bangladesh is not constitutional or administrative but political. Political parties themselves create electoral problems in Bangladesh. Thus, to defeat the political crisis by political institutionalization among responsibility and tolerance is vital for the country to exercise democracy. In short, the future researchers might straighten in their further study on the governmental investigation in Bangladesh.
\end{abstract}

Keywords: Public-Administration, Governance, Bangladesh, Shaikh Hasina, Khaleda Zia, DynasticGovernment.

\section{INTRODUCTION}

Notwithstanding that, Bangladesh appeared as a democratic republic 1972 through a murderous war of freedom with the then West Pakistan after independence on December 16, 1971 (Chowdhury, 2015), the process of democratization in Bangladesh has been faltering since freedom. The study examines the political system of Sheikh Hasina and Khaleda Zia and democratic governance in Bangladesh and explains the various reasons for strengthening democratic governance in Bangladesh (Shukla, 2017) and (Chowdhury, 2015).

In the end, the paper will make some recommendations for overcoming the problems of democratic administration in Bangladesh. Despite having two prominent women leaders in the country, women's participation in politics in Bangladesh is minimal. Sheikh Hasina and Khaleda Zia achieved the highest leadership positions in the government and the opposition through their family connections due to the low level of political institutions and the absence of suitable male heirs. Since 1991, there has been female Prime Minister and a female Leader of the opposition in the Parliament of Bangladesh. In South Asia, since the 1960s, many women have gained top leadership positions in government and opponent through their blood bonds (Khan, 2019). The first question of this research is what kind of democracy that practicing by political leaders in Bangladesh?

\footnotetext{
* Copyright (c) 2021 Mohammad Eisa Ruhullah and Zuly Qodir

This work is licensed under a Creative Commons Attribution-ShareAlike 4.0 International License.
}

Received: December 4, 2020; In Revised: January 19, 2021; Accepted: January 25, 2021 
Furthermore, Bangladesh appears fortunate as the civilian rule survived to this day after the removal of Ershad (1990) and the exceptional demand for a military role, with almost regular transfers of power after the expiration of the respective terms of Khalida and Hasina (Md. Rafiqul Islam, 2016). Nevertheless, the behavior of these two politicians and their party has led many observers to appreciate the days of military rule. Opposition boycotts, resignations, strikes, growing religious extremism and street violence have always marked the end of the two women's tenure. The authoritarian nature of politicians has tarnished the reputation of the local democratic system. After the victory in 2008, the endowment of civilian rule by Hasina appeared to be a healthy sign for the Democrats, but the Fifteenth Amendment not only eliminated the caretaker system but also made future amendments almost impracticable (M. A. Islam et al., 2017). The second research question is, Why Bangladeshi people believed on these two women leaders?

Due to the absence of a robust political culture, Bangladeshis experienced colonial and militaristic rule, mass revolutions, as well as a presidential and parliamentary rule. Below army and executive leadership, Bangladesh's political culture was based on family and hostile interests that fostered independent cooperation and obedience rather than equality. The main suspicion of Bangladeshi democracy was its lack of real political culture. To remove all the obstacles, a particular-federal culture is needed for the development of democratic institutions, but Bangladesh suffers from a lack of all the necessary preconditions (Hasan Mubashar, 2019).

Shortly, Bangladesh applies a weak democratic practice. This combines the lack of the command of law; a deficiency of political decency; a robust civil community with sufficient political administration; confrontational politics; feeble political organizations; extortion and terrorism; plus negativity, dual standards and a deficit of toleration and mutuality (S. S. Islam, 2016) and (M. A. Islam et al., 2017). In short, presently, and historically, Bangladeshi culture has featured that conflict with real democratic values. The first is the lack of mutual trust between the political parties. Second, public confidence in government-run elections is shallow (Shanta, 2017).

Research on the political process in Bangladesh has progressed from year to year where each study has the aim of good governance processes in Bangladesh, here researchers take part in the development of research on the political and democratic process in Bangladesh where in any previous studies have not discussed in detail the themes adoptive writer.

\section{METHODOLOGY}

The researcher finds out the interest to make a creative, analytical study on the political method of Bangladesh that practicing by two ladies' leaders for more than 30 years in mutual and non-mutual competition. Shaikh Hasina and Khaleda Zia these are two dictates chairperson of their respective political parties, namely Bangladesh Awami League (BAL) and Bangladesh National Party (BNP) (Sakib, 2020). The author examines the study based on two research questions which are, a.) What kind of democracy that practicing by political leaders in Bangladesh? b.) Why Bangladeshi people believed on these two women leaders?

Moreover, the study conducted on the descriptive qualitative(Ranerup \& Henriksen, 2019) manner via secondary data analysis such as books, journals, articles, newspapers, websites, and working paper (Ullah, 2018). This research's main objects to examine the political theories that implementing by Hasina and Khaleda in Bangladesh. Furthermore, to measure democracy in their political administrations (Tasnim, 2017). However, in this article, the researcher explores the changing environment of an 
autocratic regime, which is appearing from the ordinary and legislative conditions developed by the unconsolidated republic in Bangladesh.

The researcher investigates on Shaikh Hasina's ruling policy by the Bangladesh Awami League party. The ideology of that party and its practices of democracy inter-party and governmental systems. Besides the opposition leader Khaleda Zia ruling the Bangladesh national party as a chairperson. The author planned to make the study on BNP's ruling policy to find out the implementation of the republic inside it also govern to examine the beliefs of the party's principles. Thus, the paper ends up by a comparison study on these two political parties and leaders of its in Bangladesh (M. N. Islam \& Islam, 2018). Model of Democratic Accountability as a Republic State:

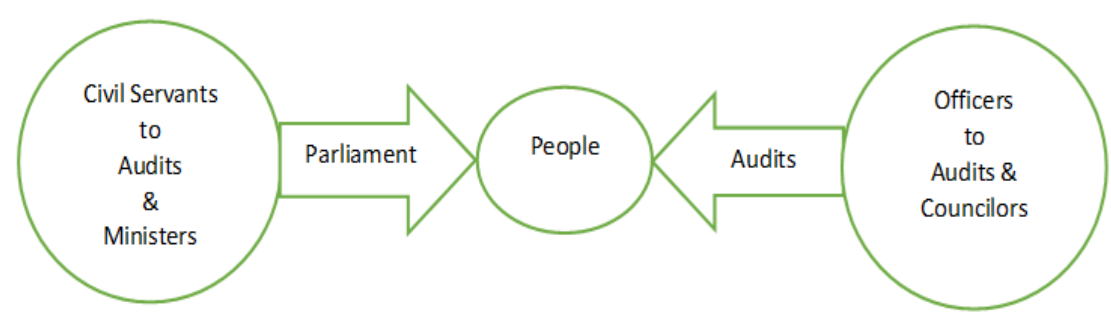

Figure 1. Central and Local Governments Accountable Method (Author, 2020 )

Pair models of the liability method are seen in the easy modem design of answerability see figure 1 as the central government and provincial government. That model reveals that all power follows from the people also the range of accountability goes through civil slaves to representatives and sequentially to Parliament, which is answerable to the people at massive. Various mechanisms obtained devised to produce governmental bodies/institutions liable both financially and for plans enforcement. According to the study of Talib extra. (2018) describes real obligation as the efficiency of a body or group to someone else, outside of the individual, as something or as some performance, wherever disciplines may follow if one neglects to convey out directives. More elegant, in his article 'Administrative Responsibility in Democratic Government' claim that one interpretation of ability may mean that a person is answerable to any agency or somebody that resolves the lines of his commitments and terms of continued profession, and exerts authority above that person (TALIB A. YOUNISIQBAL M.D. MOSTAFA, 2018).

\section{RESULT AND DISCUSSION}

\section{THE EVALUATION OF SECONDARY DATA}

\section{The backdrop of Government of the People's Republic of Bangladesh (Ages of Shaikh Hasina and Khaleda Zia)}

\section{Party's history and Ideologies that Practiced by BAL and BNP}

By the time of freedom, Bangladesh began with particular dominant party policy. The dominant party was the Bangladesh Awami League (BAL). This party was established in 1949 also soon appeared as the sound of that Bengali nationalists. This party pulled up outstanding support by championing full provincial autonomy for East Bengal and identifying Bangla as a country language. This BAL was this authoritative partner of the Juktofront coalition that mopped the Provincial Assembly votes in 1954, 


\section{IJIK, Vol.11 No. 1: 1-11}

Analytical Study of Politics in Bangladesh; Ages of Sheikh Hasina And Khaleda Zia's Dictates Mohammad Eisa Ruhullah and Zuly Qodir

demolishing this grip by the Muslim League (ML). That party led the Pakistan campaign (Jahan, 2018). It was the landslide victory of the Awami League in 1970 national elections culminated in the battle of liberation leading to the formulation of Bangladesh in 1971. Bangladesh, under the influence of Sheikh Mujibur Rahman behind the freedom, transformed toward a secular country. That constitution of 1972 put secularism as a guiding postulate of the state simultaneously with democracy, patriotism, and communism. Those four state beliefs were commanded by Mujib as his models and were popularly termed as Mujibbad. On the other hand, General Ziaur Rahman appeared as the de-facto leader in 1976. Zia expelled secularism and featured Islamic beliefs by changing the constitution (M. N. Islam \& Islam, 2018).

After the re-emergence of a republic in the beginning 1990s, the state has been alternately commanded by two first parties-Bangladesh Nationalist Party (BNP) headed by Begum Khaleda Zia, the dowager of General Zia, and Awami League directed by Sheikh Hasina, the descendant of Sheikh Mujibwith a fleeting interval of a military-backed caretaker regime. Khaleda's administration (essentially two phases, one of 1991 to 1996 (Rocha et al., 2018), and the recently from 2001 till 2006) manifested the pale reflection ofZia's method and tactic of Islamization and the constant stress of Islamic metaphor. Other side, the first phase of Hasina's administration (1996-2001) paraded no movement towards secularism and opponent to Islamization. Nevertheless, the next session (2009-2014), in coalition among the leftist parties, testified a significant shift in its governance technique-from approval of Islamization towards the method of secularization. This regime revived secularism as a country ideology; despite, paradoxically preserved Islamic idiom, and provision of country religion into the constitution (S. S. Islam, 2016), (Riaz, 2018) and (M. N. Islam \& Islam, 2018).

These authoritative political anecdotes, which ought to be conventionally constructed discursively, substantially encompassing Bangladesh's battle of liberation, proceed to polarize the Bangladeshis over and extensive. The champions consciously separate the nation for further considerable legislative mileage by culturing individual narratives at normal, political, and cerebral levels. Although Bangladesh is relatively a homogeneous nation, polarization in statesmanship, society, and history is perhaps further acute now than in seemingly an explicitly various society. The hegemonic partisan narratives possess a significant role in before-mentioned polarization (Shukla, 2017).

Furthermore, the army backed NCG governed the country for two years (2007-2008) and endeavored to implement significant governance, including political reforms. However, its plan of cleaning up politics faced various hurdles and ultimately had to be discontinued. That government's trial to democratize party politics with ousting the two heads, Sheikh Hasina and Khaleda Zia popularly named the 'Two Minus Strategy,' flunked. In the beginning, attempts were to displace the two leaders and bring democratic reforms within the two parties through some of the senior leaders of AL and BNP. Nevertheless, the two leaders denied going into deportation plus instead opted to embrace imprisonment. This 'reformist' superior leaders of both parties could not produce support from their respective parties' rank and file members upon the two dynastic heads. Subsequent failing to undermine Hasina and Khaleda in the eyes of their party members and followers, the NCG's army sponsors gave up on its 'Two Minus Strategy.' These two leaders, accompanying many other party stalwarts confined on charges of corruption, were rescued from prison, and were allowed to contest in the parliamentary vote. That ninth parliamentary election was arranged by the NCG on 29 December 2008. Repeat the 2008 parliamentary election was observed as free and fair by all internal and international witnesses. This BAL-led Grand Alliance obtained the winner with 262 chairs and 57 percent of the accessible majority. The opponent, BNP-led Four Party Alliance, obtained 34 chairs (Jahan, 2014). 


\section{IJIK, Vol.11 No. 1: 1-11}

Analytical Study of Politics in Bangladesh; Ages of Sheikh Hasina And Khaleda Zia's Dictates Mohammad Eisa Ruhullah and Zuly Qodir

\section{Democracy in Electoral Systems in Bangladesh}

The dozens of tiny and big political bodies contested the 1991 polls. However, Sheikh Hasina attended Awami League (AL), and Khaleda Zia directed Bangladesh Nationalist Party (BNP) equaled the top pair contenders. That 1991 election confirmed to obtain a watershed in the statesmanship of Bangladesh since it not only replaced the parliamentary regularity nevertheless paved the door for a democratic federal competition amongst many political partisans. Since then, particular two mainstream multitudes have been battling with each other neck to neck on the political head. Unlike salubrious democracies, the free competition for political authority in Bangladesh has extremely politicized the nation and provided rise to groups in society simultaneously party bands. That enhanced more complex when Islamic parties began gaining space (Islam Md Nazrul, 2016).

After Bangladesh became independent in 1971, its democracy holds prevailed unconsolidated, designated by tyrannical and dictatorial power within politically formed elections. December 2008 considered a different turning point while the rule was a shift to the Bangladesh Awami League (BAL) party into the national election. Following then, the BAL becomes continually remained in government. In 2014, this BAL legitimized its government throughout an election, which held boycotted via almost all opponent parties. As a sequel, 154 outwards of 300 parliamentary chairs were uncontested via the opponents' political parties. Notwithstanding, the opposition partisans involved in the 2018 polls, cumbersome election clash plus vote-rigging with the ruling BAL party appeared in the visible decline of progressive democracy in Bangladesh, notably after 2014 (R. Chowdhury, 2019), (Hasina \& Hasan, 2015) and (Mostofa \& Subedi, 2020).

The state elections have been under the method of caretaker government as the transition to political democracy in the beginning 1990s held fair and trustworthy. The people appeared to have exhibited an enthusiasm to move corresponding governments once they traversed some obscurely defined inception concerning feeble governance and contamination, as evidenced with the fall of the consecutive governments directed by the Awami League also the Bangladesh Nationalist Party (BNP). The method of the Caretaker Government becomes now been eliminated by the current Awami League regime, which considering then has combined its grip on leadership and emerged as the single authoritative party. This governance practice now looks more similar to that of the so-called combination or embodied democracy, so that one demands to reassess the country's likelihoods for continued momentum in the circumstances of such a government (Wahiduddin, 2020).

A democratic election refers to transparent and reliable elections wherever all candidates, including political riots, can associate without any tension. Voters can cast their vote smoothly without any irresolution. For Example, This Transparency International Bangladesh (TIB) has specified the 11th congressional election as 'questionable', announcing the participating political multitudes seemed not to have equal probabilities and violations dogged the election. The 18 people dead, 200 injuries, eight of these killed refer to BAL including four to BNP. Polls violence challenged at least 18 lives, executing it one of the most tedious polls in the state. More numerous than 200 others were harmed in clashes among rival Awami League and BNP advocates in 24 regions (Sansa, 2020). Strategic of India's attention in materialistic Bangladesh have reversed concerns on Hasina's dictatorial drifts. As she won indefinite uncontested re-election in 2014, the BNP did not even join because of Hasina as one-party totalitarianism, and utilitarian (Chaulia, 2019). 


\section{Violence to Dominant the Government}

Considerable advances followed the restoration of democracy in 1991 in economic, political, and social development. Nevertheless, the contemporary milieu in this densely populated nation continues to remain unstable as it experiences remarkable economic and social transformation. The main opposition Bangladesh Nationalist Party (BNP), to the obligatory Bangladesh Awami League (BAL), resorted to brutality crosswise the country after striking the elections in 2014. They were driving to constraints and harassment of crucial party leaders by the security troops. Despite, the leading BAL government has strengthened political power within maintained harassment of the opponent, and these regarded to be allied amidst it. As well as crucial voices in the media and civil society, such acts have greatly affected the opposite BNP (Kaunain Rahman, 2019).

According the study of Mostofa and Sbedi (2020), discovers that authoritarianism into Bangladesh blends "voting manipulation" among three supplementary social and executive mechanisms: "marginalization of civic opponents" heading to the oppositional void, "institutionalization of dictatorial methods," and "co-selection of religious administrators." With adding specific new mechanisms of tyrannical politics and pursuing the links within politics and theology, we endeavor to expand the principles of antagonistic authoritarianism and uncrate the bewilderment of democratic stabilization in Bangladesh (Mostofa \& Subedi, 2020).

The range of political outrage and violence against ordinary people was assumed to be low in the democratic nation compared to other political administration. However, the existing scenario of Bangladesh is dangerous. All the tools of the criminal trial system are acting as vigilant to counter political evil. Some investigations suggest some significant recommendations to lessen the extent of political misconduct in Bangladesh, which are not before-mentioned efficient. After the liberation war in 1971, there is no occurrence of the term political offence specifically. Frequently the concern of political malfeasance is discovered after the case of the assassination of the founder of Independence of Bangladesh Sheikh Mujib with his family members via some lower army officers. Afterwards, among the development of different ruling party, the nature and scope of political evil have been modified. If we examine the statistics, we can estimate the nature and bearing of political misconduct in Bangladesh. Odhikar publishes some vital statistics of the violation rate since 2001 each year. In 2001, cumulative 656 political death and 25,770 harmed for the violence of political goal, which was at altitude. The time impact of political brutality has diminished, but abruptly the amount of damage was grown to 21,265 in 2006 also 24,176 in 2013 . The extra-judicial killing was other vital kinds of the political offence committed by the country through law implementation agency which dishonors the human rights of the ordinary people of our nation (Kamruzzaman, 2018).

Moreover, traditionally both parties have practiced street anxiety, including referred to as Hartal Politics. Being a capable machine to discredit also displace the ruling authorization. After being found blameworthy in a corruption trial, BNP chairperson Khaleda Zia's custody has added one more grievance in the BNP's list of complaints against the Sheikh Hasina regime. The BNP assumes that sending its top leader behind barriers is part of the government's policy, putting her away from the electoral method. The party has frequently maintained that there will not be a reliable election in the country outwardly BNP's participation. It is also frightening to launch a political demonstration against the government if Khaleda Zia is not released, and its desire for the caretaker government is not met. Nevertheless, the BNP leaders debate that there will not be any polls without Khaleda Zia; all know that non-participation is not an alternative this time. Therefore, the party is operating hard on its poll strategy: that consists of adapting its activists for potential road agitation, including getting ready for polls. As per the newest available details, 
IJIK, Vol.11 No. 1: 1-11

Analytical Study of Politics in Bangladesh; Ages of Sheikh Hasina And Khaleda Zia's Dictates

Mohammad Eisa Ruhullah and Zuly Qodir

the party administration has finalized nominees for at least 100 constituencies and directed them to be alert and work in their particular areas for defending the votes (Shukla, 2018).

\section{DISCUSSION AND ANALYSIS VERDICTS}

\section{The Tale of Shaikh Hasina and Khaleda Zia's Political Leadership in Bangladesh}

As researcher emphasized from the literature review on the history of political leadership of Hasina and Khaleda that, Bangladesh has appeared from the other interpretation is that despite some stories of success, a 'democratic shortfall' or 'immeasurable governance deficiency' remains noticeable in Bangladesh. Political practices shifting away from the classical analysis of governments change and democratic institutionalization (M. N. Islam et al., 2020), this paper examined the political, democratic characteristics that have shaped mainly politics in Bangladesh after 1971. The political sensibilities in contemporary years have produced two distinct political sheds in Bangladesh, the BAL leaded alliance by left-wing secular individuals, and the BNP leaded combination with conservative nationalists and Islamic political partisans. Although the bifurcation is similar to most desirable democratic communities of the globe, that political relationship between, those two campsites are predestinated driven with amongst other things such as political obduracy, fundamental opponent, administrative 'totemism', and different habits of politicism. The hostility among the ruling party and the opponent, the leading party's absolute disregard for the command of the law, the diminishing value of parliamentary methods, extrajudicial assassinations, and a spiraling bearing of violence hold all remitted a critical blow to constitutionalism in Bangladesh. Notwithstanding having tremendous potentialities for democratization, those cultural habits have operated as an obstruction to democracy in Bangladesh. This current legislative culture is to obtain elections with any means constant and to abide in power by striking competitors (Salomon Heiner, Wake Caitlin, Jones Nicola, 2019).

Furthermore, during the past twenty years cycles, that has inhabited the style of political behaviour in Bangladesh, whether that was the BNP in government (1991-1996 and 2001-2006) or that BAL in leadership (1996-2001 and 2008 to the present). Following every election, there are appeals for periodic boycotts of the parliament, that withdrawal of the government and new polls. All of those movements have disturbed the budgetary growth of the country. Admittedly, the significant cause of abysmally poor governance is this bloody political history. Each leading party has remained so protected up in denying the opposition with all means that everyone has failed to surrender even the bare modicum of social duties. Toward democracy to thrive and perform effectively, there is an immediate need to improve the unfavorable political habits discussed in this study. If endeavors are not adjusted to modify the longestablished begrimed culture and schools, empowering a real republic in Bangladesh will endure a mere illusion, including the nation, will experience from an impending deadly disaster. Thus, Bangladesh demands to release itself from certain permanent political conditions so that this can move progressively in the 21st century. If democracy among 'good governance' does not allow to advance and flourish, the country will be immersed in the predicament of 'dummy-racy' (Tasnim, 2017) and (S. S. Islam, 2016).

Moreover, the conflict among parties due to the 13 th and 15 th constitutional amendment. For the fair and free election purpose with a different opinion on both bill of Non-Party Caretaker Government. It all began before the 10th Jatiya Sangsad/parliamentary referendum held on January 05, 2014, while the Bangladesh Nationalist Party (BNP), its coalition partners and several others required the election to be kept supporting by the NPCG. This leading party that Bangladesh Awami League (BAL) also its partners claimed the NPCG policy constitutionally extinct. Therefore, they impaled to the judgment that election will 
be handled under the party control, including this Election Commission (EC) command play its republican role in directing the election. Due to that variety, there grew new distrust among the two dominant political parties -these BNP and BAL. Presently, this time has reached when numerous Bangladeshis query if it will be probable to lead about political maturity or to hold a comprehensive, participatory including reliable election in Bangladesh shortly. That critical circumstances of Bangladesh politics must invite interpreters to ponder superimposed the future stability of Bangladesh statesmanship. The study endeavors to investigate that 15th Constitutional Reformation, the Caretaker Debate, including the 10th Parliamentary Election also its sequel. Considering these upshots are very much correlated with each other plus both have a severe influence on Bangladesh politics, The author has attempted to show this by examining the post-2014 election political situation of Bangladesh which may deliver us a reflection about the eternity of Bangladesh electioneering.

As the researcher find out from the previous literature that, revenge is the most significant political crisis in Bangladesh among all the parties. That is why, during every parties ruling time, there are political murders and injured, which is very typical in these days as well. A report of political violence has attached in figure 2.

\begin{tabular}{llll}
\hline \multicolumn{2}{l}{ Political Violence in Bangladesh (2001-2016) } & \\
\hline Year (s) & Killed & Injured & Total \\
\hline 2016 (Jan-March) & 56 & 3200 & 3256 \\
2015 & 197 & 8312 & 8509 \\
2014 & 190 & 9429 & 9619 \\
2013 & 504 & 24176 & 24680 \\
2012 & 169 & 17161 & 17,330 \\
2011 & 135 & 11.532 & 11.667 \\
2010 & 220 & 13,999 & 14.219 \\
2009 & 251 & 15,559 & 15,810 \\
2008 & 50 & 3.185 & 3,235 \\
2007 & 79 & 2.688 & 2.767 \\
2006 & 374 & 21,265 & 21,639 \\
2005 & 310 & 8.997 & 9,307 \\
2004 & 526 & 6.235 & 6.761 \\
2003 & 436 & 6.281 & 6,717 \\
2002 & 420 & 8.741 & 9,161 \\
2001 & 656 & 25,770 & 26.426 \\
Total & 4573 & 186530 & 191103 \\
\hline
\end{tabular}

Figure 2. The Political Violence Rate of 2001- 2016 in Bangladesh (Kamruzzaman, 2018)

The record of political violence by BAL and BNP in various places of our country of 2001 to March 2016 displays the statistics of murdered and harmed for the brutality of political ambition. That trend of political assassination and hitting over the country is standard. State murder was severe enough in the early 21 centuries. However, the level of it held at the ground in 2007-08. Later that period, political killing started rising and reached a tip of 504 in 2013, plus it has maintained until now. On the other hand injustice for political disorder ensued the same taproot as murder, but the bent injury is degenerating compared among murder (Kamruzzaman, 2018) and (Prothom Alo, 2019).

In the republic state, researcher finds about democracy from the previous writing that, the people are assumed to be the root of all power. They demand the authority to satisfy all their demands and specifications through their organizations. They additionally presume that the administration will release its constitutional commitments, not merely in the public benefit but to confirm that the people exist power. The practice of power on support of people will cause only below and by, the jurisdiction of the constitution. Conversely, into a non-democratic community, power exudes not from the civil, yet the ruler. 
There does no question of accountability on the role of the latter to estimate for his activities: in outgrowth, governance matures dictatorial. That authoritarianism, of direction, heads to the death of democratic methods, including the command of the law, electoral decision, the political haggling, that free coupling of political demands and inevitable political partnership. That most severe outgrowth of authoritarianism, nevertheless, is that this is a hindrance to adequate liability.

Thus, Bangladeshi people had encountered colonial and military government, mass upheavals, and presidential and parliamentary dominion due to the deficiency of a robust political art. Below military and parliamentary authority, Bangladesh's political farming was based on familial and heretical interests that flatten submissive docility rather than autonomous collaboration and fairness. The fundamental predicament in Bangladeshi democracy was its absence of real political history. To eradicate all obstacles, the advancement of democratic institutions demands a specific political culture. However, Bangladesh underwent an absence of crucial preconditions. Currently, plus historically, Bangladeshi culture retains features that conflict among solid democratic values. Prime is the lack of mutual trust within political parties. Next, people's determination in government-run polls is shallow.

At the instant, there are rumors of divisions inside the BNP regarding their position vis-versa participation in the eleventh parliamentary elections scheduled at the end of 2018 by the BAL government. However, the party is still existing together. Feuds between individuals and groups are also present within the BAL for nomination to parliamentary seats. Nevertheless, nobody assumes any open division in the party as long as Sheikh Hasina is the president to hold the party. In both the BAL and the BNP, there will be keen contestation within party members for designations in virtually all constituencies for this forthcoming votes. Both parties shrink that rebel competitors from within these parties can destroy the party competitors' chances in the 2018 elections. The appearance of these rebel nominees indicates weakness and indiscipline in the organizational constructions of those parties.

\section{DETERMINATION}

Starting with answering the analysis question number one that, the BNP government that was chosen in 1991 both parties rings would go on to substitute in obtaining voting and establishing a government. Except for a flunked election in February 1996 (boycotted initially by the BAL and then continued successfully in July) also the short period of the "military-backed caretaker government" in 2006-7. Nevertheless, despite national polls were widely recognized to have been comparatively open and fair (expressly those that continued held in 1991 and 1996, among less settlement in 2001) neither party wished to reform like a democratic opponent after failing an election (Moniruzzaman M, 2016) and (Abdullah, 2018).

Meanwhile what terms that era of "hope and despair", observing each election the defeated party would alternatively refuse to take up its positions in parliament, favoring to resort to extra-parliamentary movement in the form of revolution, protests and political violence to advance its political purposes. Whatever ensued did a turbulent period of "illiberal democracy" based on every party contracting and then endeavoring to deliver means to supporters, yet which nevertheless proposed a form of balance based on whatever has been defined as a method of "rotating plunder". That period of the military-backed caretaker government formed a shift. When polls were undoubtedly held in late 2008, the victorious AL resolved to do away with the caretaker government system because it was no longer wanted to ensure fair votes and repair it by an Election Commission. Games began with a new phase in 2013 while under this new method the Awami League enhanced the first party to be re-elected for a second continuous term. 


\section{IJIK, Vol.11 No. 1: 1-11}

Analytical Study of Politics in Bangladesh; Ages of Sheikh Hasina And Khaleda Zia's Dictates Mohammad Eisa Ruhullah and Zuly Qodir

Notwithstanding, the opponent BNP and its collaborators had withdrawn to take part in that election (Lewis, 2017).

Furthermore, the answer to the research question number two is this political past reflects on party politics of the state. Throughout a multiparty policy, the parties are ideologically straightened with secular, ethical, and socialist doctrines, who sustain a peculiar love-hate connection. Other than BAL also BNP, the outstanding political parties control a tiny maintenance base amongst the people. However, neither of the two parties controls unlimited support and reputation to win majority chairs in the parliament; henceforth, they form combinations with like-minded multitudes. That led to the evolution of alliancebased party statesmanship from around the mid-1980s. After that, the BAL leads a 14-party coalition, while BNP leads an 18-party combination. The BAL is leftist determined in that this is designed of secular and socialist-communist affairs. On the other hand, the BNP is admitted as rightist, with its coalition members mostly regarded with religious, national identification at the heart of their political faiths (Alam, 2017).

Notwithstanding maintaining an association structure, most of the companies, except for a miniature few, have internal factionalism also bit groups. Some of those parties sustain the same name, although with a different administration. Personally, most of those parties are merely paper-based, hold no support-base amongst the people, also are never perceive elected. Nevertheless, several of them are meaningful in coalition politics. Their political pertinence depends on their unique relationship with the housemother party, whether BAL or BNP. Since 1991, these ruling governments hold all been coalitionbased. Nonetheless, as BAL and BNP are the only two dominant parties, each with an approximately equal support base, that method can widely be denominated a two-party or two-plus party arrangement. Repeatedly, these two parties are fundamentally seen as pro-independence versus anti-independence. Ideological disagreements remain, besides some of their roles throughout the 1971 independence battle, constraining the various political parties to side among an alliance upon another (Moniruzzaman M, 2016).

Global development societies, academia, feminists, including ecologists have acknowledged "strong civil society" being one of the foundations of democracy, vigorous governance, women's empowerment, sustainable improvement, and developing political partnership. That has also implied considered mainly "the third wave" and "third path" of democracy, including the essential element of social resources. Academics and humanitarian agencies regularly emphasize the local community as a unity of the most vital instruments of systematizing democracy of this developing world also proffering them more pliable and translucent (Jinia et al., 2020).

Meanwhile, a non-democratic nation, answerability is to a distinct ideology or political partisans, whereas actual democracy appears not to countenance that. Within such a nation, people are nonconsidered the source of power; preferably, the government can govern without decent attention to each public advantage. Constitutionally, such a community has nonproper tools amidst which to make cabinet answerable. That leader or government can, in impact, abuse government and authority, among no one capable of raising questions about that role. Although liability occupies a pre-eminent place in democratic principles, one should not forget that assuring public liability is an authentic and functional test of a democratic nation (TALIB A. YOUNISIQBAL M.D. MOSTAFA, 2018).

\section{CONCLUSION}

This research resulted in the final decision on the leadership method of the two women in Bangladesh with the lack of sustainable development, political power and a lack of mutual trust and understanding between them. In addition, this study explores that the real challenge to free and fair 
national elections in Bangladesh is not constitutional or administrative but political. Political parties themselves create electoral problems in Bangladesh. Thus, to defeat the political crisis through the political institutionalization of responsibility and tolerance is very important for the country to run democracy.

Suggestion: In a democratic method, this is fundamental to have an ambitious and sophisticated party policy. However, Bangladesh has encountered a prejudiced and a confrontational body method that has produced a standoff and brought ambiguity to the whole nation. To overcome this condition, the political institutionalization with commitment and tolerance is significant for the country to practice democracy.

\section{REFERENCES}

Abdullah, A. (2018). Elections and Democracy in Bangladesh: Challenges for Free and Fair National Elections. Public Affairs And Governance, 6(1), 104. https://doi.org/10.5958/23212136.2018.00007.3

Alam, D. S. M. (2017). The Rise of an Orphan as "The Iron Lady of Asia” from the political instability after the gruesome assassination of - "Bangabandhu - The Father of the Nation. The International Journal of Social Sciences and Humanities Invention, 4(2), 3265-3276. https://doi.org/10.18535/ijsshi/v4i2.03

Chaulia, S. (2019). Victory strengthens Hasina 's foreign policy hand. Nikkei.

Chowdhury, F. D. (2015). Problems of women's participation in Bangladesh politics. Round Table, 98(404), 555-567. https://doi.org/10.1080/00358530903151748

Hasan Mubashar, A. E. R. (2019). What went wrong with the BNP, Bangladesh's main opposition party? The BNP's defeat in last year's disputed election cannot be explained solely as a result of government repression. Al Jazeera, 1-6.

Hasina, N., \& Hasan, G. S. (2015). Reconsideration of Local Government at Village Level : A Legal Reconsideration of Local Government Village Level: A Legal Study. Global Disclosure of Economics and Business, December 2015.

Islam, M. A., Ebrahimi, M., \& Yusoff, K. (2017). Major factors in the establishment of a caretaker government as an institution in Bangladesh. Man in India, 97(11), 23-36.

Islam, M. N., \& Islam, M. S. (2018). Islam, politics and secularism in Bangladesh: Contesting the dominant narratives. Social Sciences, 7(3). https://doi.org/10.3390/socsci7030037

Islam, M. N., Islam, M. S., Islam, M. N., \& Islam, M. S. (2020). Islam, Islamism, and Democracy in Bangladesh. Islam and Democracy in South Asia, 215-260. https://doi.org/10.1007/978-3030-42909-6_8

Islam Md Nazrul. (2016). God in Politics: Islam, Islamism and democracy in Bangladesh. In http://hdl.handle.net/10356/69470 (Issue July).

Islam, S. S. (2016). Good governance and political culture: A case study of Bangladesh. Intellectual Discourse, 24(2), 31-57.

Jahan, R. (2014). Political Parties in Bangladesh. Centre for Policy Dialogue.

Jahan, R. (2018). Political Parties Movements, Elections and Democracy in Bangladesh.

Jinia, N. J., Asaduzzaman, M., \& Vartola, J. (2020). Empowerment of Civil Society. Springer Nature Switzerland AG, February, 1-11. https://doi.org/10.1007/978-3-319-71060-0_2-1

Kamruzzaman, M. (2018). Political Crime in South Asia: A Theoretical Explanation. Journal of Political Science and International Relations, 1(1), 1. https://doi.org/10.11648/j.jpsir.20180101.11

Kaunain Rahman. (2019). Overview of Corruption and Anti- Corruption in Ghana. Transparency International (The Global Coalition Against Corruption), 2018, 1-18.

Khan, H. (2019). Democracy, Authoritarianism and Military Rule in Pakistan and Bangladesh: A Comparative Study. Journal of South Asian and Middle Eastern Studies, 42(4), 40-58. https://doi.org/10.33428/jsoutasiamiddeas.42.4.0040 
Lewis, D. (2017). Organising and Representing the Poor in a Clientelistic Democracy: the Decline of Radical NGOs in Bangladesh. Journal of Development Studies, 53(10), 1545-1567. https://doi.org/10.1080/00220388.2017.1279732

Md. Rafiqul Islam. (2016). The State of Democratic Governance in Bangladesh. Journal of Governance and Innovation, II(1), 1-210.

Moniruzzaman M. (2016). Electoral Legitimacy, Preventive Representation, and Regularization of $\begin{array}{llll}\text { Authoritarian } & \text { Democracy. } & \text { IntechOpen, }\end{array}$ https://doi.org/http://dx.doi.org/10.5772/57353

Mostofa, S. M. D., \& Subedi, D. B. (2020). Rise of Competitive Authoritarianism in Bangladesh. Cambridge University Press on Behalf of Religion and Politics, 1-29. https://doi.org/10.1017/S1755048320000401

Prothom Alo. (2019). 1209 people disappeared in last 10 yrs: BNP. Prothom Alo English Desk, 1011.

R. Chowdhury. (2019). Bangladesh : Sheikh Hasina 's Fear of Fall is The Issue. South Asia Journal, $1-6$.

Ranerup, A., \& Henriksen, H. Z. (2019). Value positions viewed through the lens of automated decision-making: The case of social services. Government Information Quarterly, October 2018, 101377. https://doi.org/10.1016/j.giq.2019.05.004

Riaz, A. (2018). More than meets the eye: The narratives of secularism and Islam in Bangladesh. Asian Affairs, 49(2), 301-318. https://doi.org/10.1080/03068374.2018.1467659

Rocha, K., Palazzo, J., Teczar, R., \& Clark, R. (2018). Does Breaking Through the "Final Glass Ceiling " Really Pave the Way for Subsequent Women to Become Heads of State? By Katherine Rocha, Joseph Palazzo , Rebecca Teczar and Roger Clark. In Rhode Island College.

Sakib, S. N. (2020). Bangladesh to free jailed opposition chief for 6 months. Www.Aa.Com.

Salomon Heiner, Wake Caitlin, Jones Nicola, M. Q. (2019). Four priorities for Bangladesh 's new government in 2019. Overseas Development Institute.

Sansa, A. N. (2020). Electronic Research Journal of Social Sciences and Humanities ISSN: 2706 8242 www.eresearchjournal.com Vol 2: Issue I Jan - Mar 2020. Electronic Research Journal of Social Sciences and Humanities, 2(I), 168-172.

Shanta, H. A. (2017). The Caretaker Debate, 10th Jatiya Sangsad Elections and Recent Trends in Bangladesh Politics. South Asian Studies, 32(2), 523.

Shukla, A. (2017). The Changing Political Dynamics in Bangladesh. Indian Council of World Affiars, February 1991.

Shukla, A. (2018). BNP' s Narrowing Options in Bangladesh. Www.Icwa.In, 1-5.

TALIB A. YOUNISIQBAL M.D. MOSTAFA. (2018). ACCOUNTABILITY IN PUBLIC MANAGEMENT AND ADMINISTRATION IN BANGLADESH. In Routledge Revivals- Taylor \& Francis Group (Vol. 66).

Tasnim, F. (2017). Politicized civil society in Bangladesh: Case study analyses. Cosmopolitan Civil Societies, 9(1), 98-123. https://doi.org/10.5130/ccs.v9i1.5247

Ullah, W. (2018). Local Government in Bangladesh : Women 's Participation and Empowerment. International Journal of Natural and Social Sciences, 5(4), 99-107.

Wahiduddin, M. (2020). Socio-Economic Progress with Poor Governance: How are Amartya Sen's Thoughts Relevant for Contemporary Bangladesh? Ergonline.Org, 1-17. 